\title{
Maxillofacial injuries managed at Tribhuvan University Teaching Hospital, Kathmandu, Nepal: a 7 year retrospective study
}

\author{
Krishna KC ${ }^{1}$, Jayan Man Shrestha ${ }^{2}$ \\ ${ }^{1}$ Assistant professor, Maxillofacial surgery, Department of dental surgery, Tribhuvan University Teaching Hospital, Maharajgung \\ ${ }^{2}$ Associate professor, Department of Plastic Surgery, Tribhuvan University Teaching Hospital, Maharajgunj
}

Correspondence: Dr. Krishna KC, TU Teaching Hospital, Maharajgunj, Kathmandu, Nepal

Email:drkrishnakc@hotmail.com

\begin{abstract}
Introduction: Of all the facial injuries, maxillofacial region is one most frequently involved. The maxillofacial region is most prone to trauma owing to its prominent position in the skull which gets involved easily in case of trauma. Facial injuries can have long term consequences in terms of esthetics and function. Few series have been studied in terms of incidence of facial trauma in Nepal.

Methods: We performed a retrospective analysis of all the patients admitted and treated at the surgery and dental department of the Tribhuvan University teaching hospital with the diagnosis of facial injuries over the period of 8 years (2008 to 2016). The characteristics of these injuries were analyzed. The causes of injury were classified as follows: traffic accidents, assaults, animal attacks, falls, sports and related to the disaster. Anatomically, fractures of the mandible were classified into following regions: symphysis, parasymphysis, canine, body, angle, condyle and fractures more than one site (multiple sites). Midface fractures were classified according to the Le fort classification into Le fort I, Le Fort II, Le fort III and ZMC.

Results: A total of 133 patients with facial fractures were treated between 2008 and 2016 which were retrospectively analyzed. The male: female ratio was $2: 1$ and the largest subgroup of patients were between 16 and 30 years of age. The most common cause of injury was road traffic accidents $(62.4 \%)$ involving motorcycles or automobiles. Other common causes included, in descending order, falls (5.2\%), animal attacks (5.2\%) assaults (3.7\%) and sports. Isolated mandibular fractures were most common $(50.4 \%)$, followed by isolated Zygomaticomaxillary complex (ZMC) fractures $(18.8 \%)$. The percentage of fractures involving Le fort I was $8.3 \%$, and that of isolated alveolar fractures was $9 \%$.

Conclusion: RTAs remains the main cause for maxillofacial injuries where males were predominately affected, condition of the roads, traffic regulations and adverse weathers all contribute to the TRAs in developing countries like Nepal.

Key words: Disaster, fall injuries, interpersonal violence, maxillofacial trauma, road traffic accidents
\end{abstract}

\section{Introduction}

The maxillofacial region is most prone to trauma owing to its prominent position. ${ }^{1,2}$ Its externalexposure to the oral environment is maximalin comparison to the rest of the body. ${ }^{3}$ These facial fractures can have long-term consequences, both functionally and aesthetically. The causes of facial injury are influenced by socioeconomic factors. However, few maxillofacial trauma series have been studied in Nepal and little information is available on their relative incidence and fracture patterns. The world health organization statistics indicate that 1 million people die and 20 to 30 million injured annually in road traffic accidents (RTA). ${ }^{4}$ 
In developing countries like India, Nigeria and in few developed countries of the east like Japan an Singapore, RTA represent the most common cause of maxillofacial injuries. ${ }^{3,5,8-10}$ Similar result was observed in few developed countries in Europe like Denmark too. ${ }^{6}$ However, in countries like Finland, Sweden and United States physical assault have been the most common cause of maxillofacial injuries. ${ }^{11-13}$

We retrospectively analyzed the characteristics of facial fractures treated at our hospital during the past 7 years to study the principal causes of injury and the relation between causes and fracture pattern.

\section{Methods}

We performed a retrospective analysis of all the patients admitted and treated at the surgery and dental department of the Tribhuvan University teaching hospital with the diagnosis of facial injuries over the period of 8 years (2008 to 2016). The characteristics of these injuries were analyzed. The causes of injury were classified as follows: traffic accidents, assaults, animal attacks, falls, sports and related to the disaster. Anatomically, fractures of the mandible were classified into following regions: symphysis, parasymphysis, canine, body, angle, condyle and fractures more than one site (multiple sites). Midface fractures were classified according to the Le fort classification into Le fort I, Le Fort II, Lefort III and ZMC.

\section{Results}

.In the period 2008 to 2016,133 patients with maxillofacial injuries were treated at the TU Teaching Hospital. There were 88 male patients $(66.2 \%)$ and 45 (33.8\%) female patients (Figure 1). The patients ranged from 3 to 73 year age group.

A number of parameters, including age, gender, cause of injury, site of injury, type of injury were evaluated. All maxillofacial injuries were assessed and treated by a single oral and maxillofacial surgeon and the cases with soft tissue loss were repaired by plastic surgeon. Other concomitant bodily injuries were treated by appropriate consultant specialists.

\section{Etiological variation}

We observed that RTA is the most common cause of the maxillofacial injuries $(62.4 \%)$ followed by fall, animal attacks (5.2\%), interpersonal violence $(3.7 \%)$ and disaster (18.7\%) (Table 1).

\section{Age and sex distribution}

Males were commonly affected $66.2 \%(88)$ as compare to females $33.8 \%(45)$. The age group of 16 to 30 years were predominately affected(53.4\%) followed by 31 to 45 years $(17.3 \%)$.

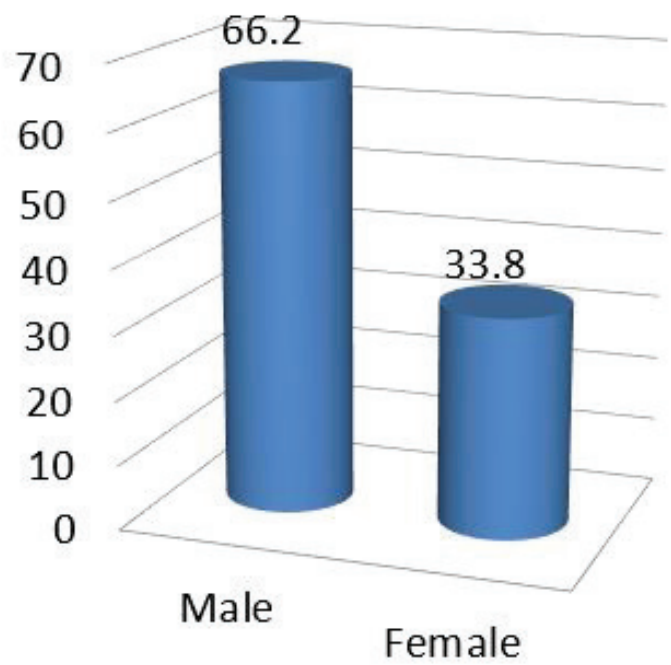

Figure 1: male to female proportion

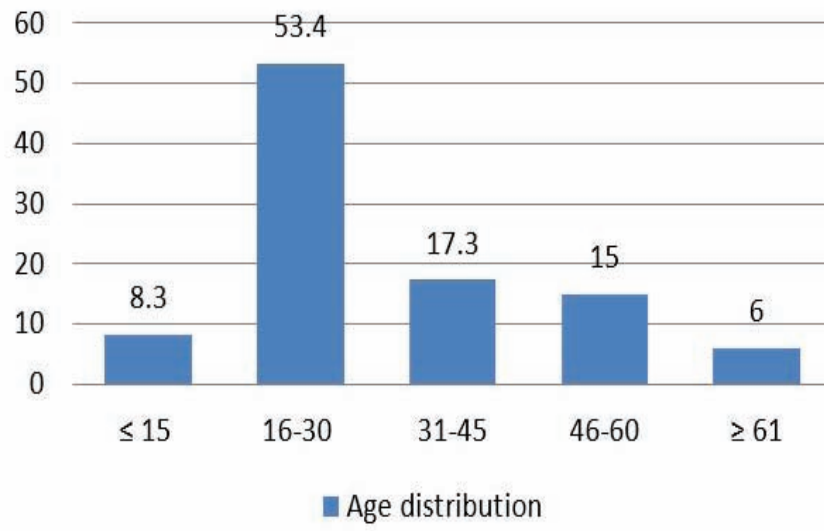

Figure 2: age distribution

\section{Geographical variation}

Most of the RTA occurred in the urban areas, only few occurred in the hilly region due to the adverse weather and bad roads. All the cases of animal attacks were in the mountain region. $71 \%$ of the animal attack was by bear, $14 \%$ by domestic animals followed by tiger (14.28\%). 


\section{Site and etiology distribution of maxillofacial injuries}

67 cases had mandibular fractures, 10 had symphysis, 13 had parasymphysis, 8 had condyle and 22 cases had fractures on multiple sites (Table 2). Most were affected by RTA $(54.2 \%)$ followed by fall from the height. All the cases of animal attacks had multiple sites injury.

Table1: Site and etiological distribution of maxillofacial injuries.

\begin{tabular}{|c|c|c|c|c|c|c|c|c|}
\hline Etiology & $\begin{array}{l}\text { Mandibular } \\
\text { fractures }\end{array}$ & Others & Le fort I & Le fort II & $\begin{array}{l}\text { Lefort } \\
\text { III }\end{array}$ & ZMC & $\begin{array}{l}\text { Pan } \\
\text { facial }\end{array}$ & Total \\
\hline RTA & $45(54.2 \%)$ & 12 & 5 & 1 & 2 & 12 & 6 & $\begin{array}{l}83 \\
(62.4 \%)\end{array}$ \\
\hline $\begin{array}{l}\text { Physical } \\
\text { assault }\end{array}$ & 2 & & 1 & & & 2 & & 5 (3.7\%) \\
\hline $\begin{array}{l}\text { Fall from } \\
\text { height }\end{array}$ & 4 & & & & & 2 & 1 & 7(5.2\%) \\
\hline $\begin{array}{l}\text { Animal } \\
\text { attacks }\end{array}$ & 3 & & & & & 3 & 1 & $7(5.2 \%)$ \\
\hline $\begin{array}{l}\text { Sports } \\
\text { injuries }\end{array}$ & 1 & & & & & 2 & & $3(2.2 \%)$ \\
\hline Disaster & 10 & & 5 & 2 & 1 & 3 & 4 & $25(18.7 \%)$ \\
\hline $\begin{array}{l}\text { Gunshot } \\
\text { injury }\end{array}$ & 2 & & & & & 1 & & $3(2.2 \%)$ \\
\hline Total & $67(50.4 \%)$ & $12(9.0 \%)$ & $11(8.3 \%)$ & $3(2.2 \%)$ & $3(2.2 \%)$ & $25(18.8 \%)$ & $12(9.0 \%)$ & 133 \\
\hline
\end{tabular}

Table2: Site and etiological distribution of mandibular fractures.

\begin{tabular}{|c|c|c|c|c|c|c|c|}
\hline \multirow{2}{*}{$\begin{array}{l}\text { Causes of } \\
\text { injury }\end{array}$} & \multicolumn{7}{|c|}{ Site of mandibular fracture } \\
\hline & Symphysis & parasymphysis & $\overline{\text { Body }}$ & Angle & Condyle & $\begin{array}{l}\text { Multiple } \\
\text { sites }\end{array}$ & Total \\
\hline RTA & 5 & 10 & 1 & 10 & 6 & 13 & 45 \\
\hline Fall from height & 2 & & & & 1 & 1 & 4 \\
\hline Physical assault & & 2 & & & & & 2 \\
\hline Gunshot injury & 1 & & 1 & & & & 2 \\
\hline Disaster & 2 & 1 & & 2 & & 5 & 10 \\
\hline Animal attack & & & & & & 3 & 3 \\
\hline Sports injury & & & & & 1 & & 1 \\
\hline Total & 10 & 13 & 2 & 12 & 8 & 22 & 67 \\
\hline
\end{tabular}

\section{Associated injuries with the maxillofacial injury}

Out of 133 maxillofacial injuries, 60 males (45.1\%) had isolated maxillofacial injuries whereas 31 females (23.3\%) had isolated maxillofacial injuries. 14 patients had associated head injuries (10 males and 4 females), 18 patients had associated orthopedic injuries (11 males and 7 females), 7 patients had associated ophthalmic injuries ( 5 males and 2 females) and 3 patients had associated cervical spine injuries ( 2 males and 1 female) (Table 3 ). 
Table3: Associated injuries with maxillofacial injuries.

\begin{tabular}{llcl} 
Site & \multicolumn{2}{c}{ sex } & $\begin{array}{l}\text { Total no of } \\
\text { patients }\end{array}$ \\
& male & female & \\
$\begin{array}{l}\text { Isolated } \\
\text { maxillofacial } \\
\text { surgery }\end{array}$ & 60 & 31 & $91(68.4 \%)$ \\
$\begin{array}{l}\text { Associated } \\
\text { head injury }\end{array}$ & 10 & 4 & $14(10.5)$ \\
$\begin{array}{l}\text { Ophthalmic } \\
\text { injury }\end{array}$ & 5 & 2 & $7(5.2 \%)$ \\
$\begin{array}{l}\text { Orthopedics } \\
\text { injury }\end{array}$ & 11 & 7 & $18(13.5 \%)$ \\
$\begin{array}{l}\text { Cervical } \\
\text { spine injury }\end{array}$ & 2 & 1 & $3(3.4 \%)$ \\
Total & 88 & 45 & 133
\end{tabular}

\section{Discussion}

Factors such as road traffic regulations, drink and drive legalization, socioeconomic status and geographic locations influences the incidences of maxillofacial injuries. ${ }^{14}$ Owing to the prominent position of the facial skeleton, these bones are more prone to the trauma as compare to the other bones in the body. The mandible being more prominent is often involved in the trauma, the shape of the face is influenced largely by bone scaffold, and therefore the ZM complex and arch present as important structures in facial contour. ${ }^{15}$ The brittle anatomic architecture of the midfacial region makes it the most liable to injury, causing considerable disruption in skeletal integrety. ${ }^{3}$

Apart from various causes of maxillofacial injuries mention in the literature, most of the literature regarded RTAs as the predominant factor responsible for the maxillofacial injury. In our study, $62.4 \%$ injuries were due to RTA followed by animal attacks and interpersonal violence. Even though the $18 \%$ cases were due to disaster we cannot consider it as main cause owing to rarity of the frequency of disaster. A vast majority of the RTA were during 2009 till 2013 due to the traffic regulation in those days, drink and drive legalization was not in the effect so $50 \%$ of the maxillofacial injuries were associated with the alcohol abuse. After the law was reformed RTA drastically decreased. In Sweden, alcohol or narcotics involvement in facial fracture had been reported as high as $56 \%$ and most of the violence linked to alcohol abuse. ${ }^{12}$ Social gathering and festival season with the social gathering contributed to the most of the cases which were similar to the pattern observed in India. ${ }^{3,16}$

As for the age and sex distribution males were more frequently affected as compare to the females. The age groups predominately affected were in between 16 to 30 years $(53.4 \%)$. The sex distribution shows males $(66.2 \%)$ were mostly involved whereas (33.8\%) females were involved making the ratio 2:1. Young individuals were involved in RTA whereas older individuals were involved in falls. In an analysis of 1502 patients with facial fractures at Japan, a male majority of $73.9 \%$ was observed. ${ }^{17}$ Our results were almost similar to the previous studies.

In regards to the injury pattern $68.4 \%$ had isolated maxillofacial injury, $18 \%$ had orthopedics injury mostly lower limbs, 14\% had head injury and 7\% had ophthalmic injury. In case of midface fracture almost $70 \%$ had subconjunctival hemorrhage which was similar to Jamal et al who observed $66 \%$ of subconjunctival hemorrhage.

All maxillofacial injuries were assessed and treated by a single oral and maxillofacial surgeon and cases where soft tissue loss were to be repaired plastic surgeon was involved. Other concomitant bodily injuries were treated by appropriate consultant specialists. There were 112 cases were operated under general anesthesia and 21 cases were treated under local anesthesia. Cases of dento alveolar fractures were treated by splinting the arch with Erich arch bars for 4 weeks. Condylar fractures were approached via retromandibular approach and other mandibular fractures via intraoral incisions. Cases with previous lacerations were approached via submandibular, the mid face fractures by vestibular de-gloving, ZF region via supraorbital incision and infraorbital rim via subcillary incisions, gillies temporal approached was used for the arch elevation.

\section{Conclusion}

The main etiological factor for the maxillofacial injuries continues to be RTAs where males were predominately affected. Condition of the roads, traffic regulations and adverse weathers all contribute to the RTAs in developing countries. Our country being more dependent in the agriculture in context of geography animal attacks were more frequent as peoples habitats are near the forest. Injuries of the maxillofacial region needs prompt recognition and appropriate management as times these injuries are associated with other injuries, coordination with the other specialties is also required at times. ORIF is the method of choice for the treatment of maxillofacial injuries. 


\section{References}

1. Motamedi MHK.Assessment of maxillofacial fractures: a 5-year study of 237 patients. J oral Maxillofac Surg 2003; 61:61-64. PMid:12524610 https://doi.org/10.1053/joms.2003.50049

2. Gassner R, Tuli T, Hachl 1, Rudisch A,Ulmer H.Cranio-maxillofacial trauma: a 10 year review of 9,543 cases with 21, 067 injuries. J Craniomaxillofac Surg 2003; 31:51-61 https://doi.org/10.1016/S10105182(02)00168-3

3. Kamath RAD, Bharani S, Hammannavar R, Ingle SP, Shah AG.Maxillofacial Trauma in central Karnataka, India:An outcome of 95 cases in a regional Trauma care centre.Craniomamillofac Trauma Recon 2012; vol 5: 189-254 PMid:24294401 PMCid:PMC3577598

4. Statistics annual WHO1992.Geneva, Switzerland: WHO; 1992

5. Tanaka N, Tomitsuka K, Shionoya K, et al. Aetiology of maxillofacial fracture. $\mathrm{Br} \mathrm{J}$ Oral Maxillofac Surg 1994; 32:19-23 https://doi.org/10.1016/02664356(94)90166-X

6. Marker P,Nielsen A, Bastian HL. Fractures of the mandibular condyle part 1: patterns of distribution of types and causes of fractures in 348 patients. Br J Oral Maxillofac Surg 2000; 38:417-421. PMid:11010766 https://doi.org/10.1054/bjom.2000.0457, https://doi. org/10.1054/bjom.2000.0317

7. Kieser J, Stephenson S, Liston PN, Tong DC, Langley JD. Serious facial fractures in New Zealand from 1979 to 1998. Int J Oral Maxillofac Surg 2002; 31:206-209, https://doi.org/10.1054/ijom.2002.0208 PMid:12102421

8. Tay AG, Yeow VK, Tan BK, Sng K, Huang MH, Foo CL. A review of mandibular fractures in a craniomaxillofacial trauma centre. Ann Acad Med Singapore 1999; 28:630-633 PMid:10597345

9. Olasoji HO, Tahir, Arotiba GT. changing picture of facial fractures in northen Nigeria, Br J Oral Maxillofac Surg 2002;40:140-143. PMid:12180207 https://doi org/10.1054/bjom.2001.0716
10. Bataineh AB. Etiology and incidence of maxillofacial fractures in the north of Jordan. Oral Surg Oral Med Oral Pathol Oral Radiol Endod 1998;86:31-35 https:// doi.org/10.1016/S1079-2104(98)90146-9

11. Oikarinen K, Ignatius E, Kauppi H,Silvennoinen U.Mandibular fractures in northern Finland in the 1980s-a 10 year study. Br J Oral maxillofac Surg1993;31:23-27 https://doi.org/10.1016/02664356(93)90092-B

12. Storm C, Nordenram A, Fischer. Jaw fractures in the country Kopparberg and Stockholm 1979-1998-a retrospective cooperative study of frequency and cause with special reference to assault. Swed Dent 1991; $15: 285-289$

13. Ogundare BO, Bonnick A, Bayley N. Pattern of mandibular fractures in an urban major trauma center. J oral maxillofac Surg 2003; 61:713718. PMid:12796884 https://doi.org/10.1053/ joms.2003.50118

14. Gomes PP, Passeri LA, Barbosa JR. A five year retrospective study of Zygomatico-orbital complex and Zygomatic arch fractures in Sao Paulo State, Brazil. J oral Maxillofac Surg 2006; 64:63-67. PMid:16360858 https://doi.org/10.1016/j.joms.2005.09.012

15. Vetter JD, Topazian RG, Goldberg MH, Smith DG. Facial fractures occurring in a medium sized metropolitan area: recent trends. Int J Oral Maxillofac Surg 1991; 20:214-216. https://doi.org/10.1016/ S0901-5027(05)80177-8

16. Subhashraj K, nandakumar N, Rabindran C. Review of maxillofacial injuries in Chennai, India; a study of 2748 cases. Br J Oral Maxillofac Surg 2007; 45:637639. PMid:17524534 https://doi.org/10.1016/j. bjoms.2007.03.012

17. Iida S, Kogo M, Sugiura T, Mima T. Matsuya T: Retrospective analysis of 1502 patients with facial fractures. Int J Oral Maxillofac Surg 2001; 30: 286-290. PMid:11518349 https://doi.org/10.1054/ ijom.2001.0056 